\title{
Plant diversity and chemical soil composition of rocky pastures in relation to the sheep grazing intensity on the northern Adriatic islands (Croatia)
}

\author{
Ivica Ljubičić $^{1 *}$, Mihaela Britvec ${ }^{1}$, Sven D. Jelaska ${ }^{2}$, Stjepan Husnjak $^{3}$ \\ ${ }^{1}$ University of Zagreb, Faculty of Agriculture, Department of Agricultural Botany, \\ Svetošimunska 25, 10000 Zagreb, Croatia \\ ${ }^{2}$ University of Zagreb, Faculty of Science, Department of Botany, Marulićev trg 20, \\ Zagreb, Croatia
}

${ }^{3}$ University of Zagreb, Faculty of Agriculture, Department of Soil Science, Svetošimunska 25, Zagreb, Croatia

\begin{abstract}
Optimal grazing pressure on rocky pastures is beneficial to the development of plant species and maintenance of plant diversity. Both abandonment of grazing and overgrazing gradually reduce plant diversity. This paper correlated abundance patterns of the flora on rocky pastures with the values of the chemical composition of the soil resulting from the degree of sheep grazing intensity. The study was carried out in the period from 2008 to 2010 on the islands of Pag, Krk and Cres. At 30 sites, 310 taxa of vascular plants were found. The highest plant diversity and 220 plant taxa were found on moderately grazed pastures. Abandoned pastures with a total of 93 plant taxa observed show the dominance of phanerophytes $(35.5 \%)$ and the highest proportion of the Mediterranean floral element when compared to pastures of moderate and heavy grazing intensity. The highest concentration of total nitrogen in the soil $(0.71 \%)$ was recorded on plots of heavy grazing intensity. The results of the study indicate that moderate grazing intensity, from 1 to 1.5 sheep ha ${ }^{-1}$, can be recommended on the northern Adriatic islands. This should contribute not only to the preservation of plant diversity, but also to the improvement of ecological sheep farming.
\end{abstract}

Keywords: chemical composition of the soil, Mediterranean flora, rocky pasture, sheep grazing intensity

\section{Introduction}

Pastures are extremely important habitats that significantly increase plant diversity because they are inhabited by many rare plant species. Nevertheless, they are also endangered

*Corresponding author, e-mail: iljubicic@agr.hr 
due to overgrazing resulting from high livestock density or due to the abandonment of traditional sheep breeding resulting in progressive succession.

The method of pasture management is particularly important for sustainability of plant diversity. In the northeastern part of Spain three sheep grazing intensities were studied on pastures along climatic gradients, and it was shown that the increase of grazing intensity may reduce or increase plant diversity, depending on the amount of water and nutrients in the soil available to plants (DE BELLO et al. 2007). High grazing intensity treatment and pasture abandonment cause a reduction in floristic diversity and biomass (ŠKKORNIK et al. 2010). Depending on climatic conditions and soil fertility, various models have been developed to show that the intensity of sheep grazing affects plant diversity (MilchunAs et al. 1988, Proulx and Mazumder 1998, Cingolani et al. 2005). ŠKornik et al. (2010), found that for the preservation of plant diversity in dry grassland in the northern Adriatic karst pastures moderate grazing intensity with 4-7 sheep ha ${ }^{-1}$ was the most appropriate. Furthermore, high intensity of sheep grazing increased the dominance of ruderal plants and reduced the proportion of chamaephytes and geophytes. Overgrazing may in extreme cases lead to total destruction of plant communities (Horvat 1949, Puerto et al. 1990, Montalvo et al. 1993), and is often perceived as a major factor in the degradation of Mediterranean ecosystems and landscapes (Noy-Meir and Oron 2001). However, many such ecosystems, when they are undergrazed or entirely abandoned, tend to become impenetrable woody thickets with low species diversity.

Overgrazing in hot and dry areas with shallow soils on a rocky substrate will result in the development of barren, rocky ground as is the case today in large areas of the Mediterranean coastline (PECO et al. 1998, ElER et al. 2005). Such habitats with rocky soil have a limited amount of water and nutrients available to plants, thus the increase of grazing pressure adds to the reduction of plant species diversity (PROULX and MAZUMDER 1998). In recent decades, the cessation of extensive method of pasture management has been related to the modernization of livestock breeding (Rook et al. 2004). Abandonment of grazing in some parts of Europe has led to the loss of grassland and the disappearance of certain plant species, so the remaining, preserved grasslands tend to be granted protected status (Cousins and ERIKSSON 2001). Furthermore, HE et al. (2011), carried out a study on the importance of grasslands as a potential source of nitrogen and carbon and suggested that the accumulation of these nutrients in the soil at two depths $(0-30$ and $30-60 \mathrm{~cm})$ decreased linearly with the increase of grazing pressure. This indicates that the accumulation of nutrients at a depth down to $30 \mathrm{~cm}$ is significantly higher in moderately grazed than in more heavily grazed grasslands, thus showing that moderate grazing intensity brings about the mobilisation of nutrients in the soil, while high grazing intensity results in loss of carbon and nitrogen, the threshold for the transformation being 4.5 sheep $\mathrm{ha}^{-1}$. Overgrazing may hamper productivity and cause serious loss of nutrients in the soil, thereby decreasing soil fertility (RIETKIRK and VAN DE KOPPEL 1997, Su et al. 2005, HAN et al. 2008). Grazing may also affect the mechanical properties of the soil because the increase of grazing pressure increases soil compaction (KNAPP et al. 1999). Overgrazing, trampling and pollution favor the creation of anthropogenic communities which with constant accumulation of manure are transformed into extremely nitrophilous vegetation cover (Derner and Schuman 2007, Ingram et al. 2008). Basically, high grazing pressure tends to decrease plant diversity and biomass and facilitates spatial homogeneity (Augustine and McHaughton 1998, Frank and Groffman 1998). 
Changes in the intensity of grazing may lead to an increasing number of uncultivated and overgrown soils (BIONDI et al. 2005). Over the past years, the process of abandonment of rocky pastures on the island of Pag has proceeded rapidly and large pasture areas have been turned into macchia, the most common taxa coming from the genus Juniperus (LuUBIČIĆ 2008).

The aim of the present study was to compare the composition of the floras on the rocky pastures of the northern Adriatic islands of Pag, Krk and Cres, to determine the dependence of the floristic composition on the chemical composition of the soil resulting from the degree of sheep grazing intensity, and to determine the optimal grazing pressure, an essential factor in the maintenance of plant diversity.

\section{Materials and methods}

\section{Study area and data sampling}

The studied areas were rocky pastures of the islands of Pag, Krk and Cres, belonging to the group of northern Adriatic islands (Fig. 1). This is a transitional area between the eumediterranean zone and the submediterranean zone. With some exceptions, it still contains the basic characteristics of the Mediterranean climate. Due to the climatic conditions, evergreen and deciduous vegetation types are present together. Average annual air temperature is $15.5^{\circ} \mathrm{C}$ with an average annual precipitation of $1,113 \mathrm{~mm}$. Geological bedrock is composed mainly of carbonate sediments with inclusion of limestone dolomite rocks, and the

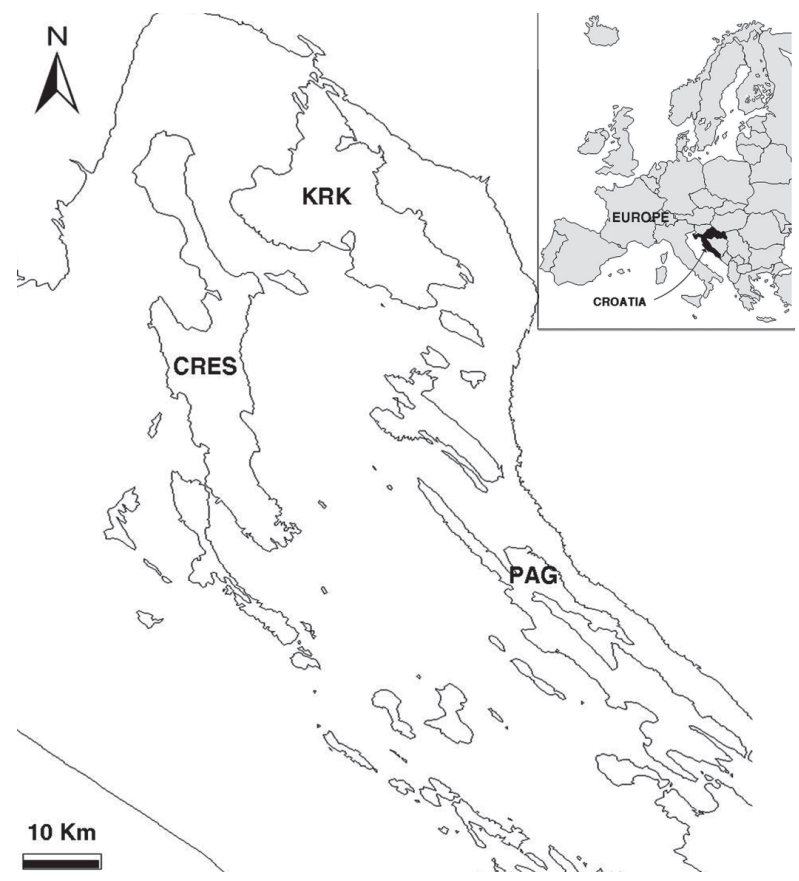

Fig. 1. Overview of studied area of rocky pastures on the northern Adriatic islands of Pag, Krk and Cres. 
islands have predominantly the following soil types: rocky soil, limestone dolomite black soil, rendzina, brown soil on limestone and dolomite, terra rossa soil and anthropogenic karst soils. These types of soils are often composed of more or less heterogeneous soil combinations (HuSNJAK et al. 2008). The studied area belongs to the alliance Chrysopogoni-Saturejon Ht. et H-ić 1934, namely eastern Adriatic rocky pastures vegetation of the subMediterranean zone in the Mediterranean littoral vegetation belt. Within this alliance most prominent are the following communities: Koelerio splendenti-Festucetum illyricae Trinajstić 1992, Stipo eriocauli-Salvietum officinalis H-ić (1956) 1958 and Asphodelo aestivo-Chrysopogonetum grylli H-ić (1956) 1958 (TRINAJsTić 2008).

The study was carried out during the growing seasons of 2008, 2009 and 2010. During the sampling we tried to cover the largest range of variability in nature possible. The data are organized within two matrices of data. The first matrix represents the abundance (the cover of certain species on the plot), while in the second matrix each plot is assigned to the values measured of the following variables: total nitrogen in the soil $(\mathrm{N})$, physiologically active phosphorus $\left(\mathrm{P}_{2} \mathrm{O}_{5}\right)$ and potassium $\left(\mathrm{K}_{2} \mathrm{O}\right)$, soil $\mathrm{pH}$, humus content, organic matter content, method of land use, grazing pressure, altitude, terrain slope and exposure.

Vascular plants were studied at 30 sites. The choice of plots was made according to the intensity of sheep grazing, and therefore 10 sites on rocky pastures abandoned for more than 20 years were selected, as well as 10 with moderate intensity (1-1.5 sheep ha $\left.{ }^{-1}\right)$ and 10 localities with heavy grazing intensity $\left(\geq 8\right.$ sheep ha $\left.{ }^{-1}\right)$. Each site was represented by two plots, which makes a total of 60 plots. The plots of abandoned pastures are numbered 1 to 8 (island of Pag), 21 to 26 (island of Krk) and 45 to 50 (island of Cres), moderate-intensity grazing plots are numbered: 9 to 14 (island of Pag), 27 to 34 (island of Krk) and 51 to 56 (island of Cres) while plots of heavy intensity grazing are numbered 15 to 20 (island of Pag), 35 to 44 (island of Krk) and 57 to 60 (island of Cres). The plot area was chosen with respect to the intensity of sheep grazing: for abandoned pastures $15 \times 15 \mathrm{~m}$, moderate $10 \times 10 \mathrm{~m}$ and heavy intensity $10 \times 10 \mathrm{~m}$ plots. The floristic composition was sampled at full flowering (May, June) and before release of sheep to pasture. The life forms of plants were aligned according to Pignatti (1982), and the endemic, endangered and allochthonous taxa according to Nikolić (2013). A floristic list with the respective abundances was made according to Braun-Blanquet method (Horvat 1963). Nomenclature of plant taxa follows Flora Croatica Database (NiKOLIĆ 2013).

Soil sampling was carried out during and after sheep grazing within the growing season. This methodology has been used in similar studies of grazing pressure (ELER et al. 2005; DE BELlo et al. 2007; ŠKORNIK et al. 2010). The studied rocky pastures are located mainly on skeletoidal soils and the mentioned nutrient content applies only to fine-grained soil. Therefore, when assessing the content of total nitrogen and other nutrients, analytical data must be considered within this context. Soil sampling was conducted to measure the long-term role of sheep as vectors of nutrients on rocky pastures. Samples were taken up to a depth of 25 $\mathrm{cm}$ in the upper layer of the pedosphere according to the method of SALMINEN et al. (1998).

The studied pasture plots were grazed by landrace sheep breeds (from Pag, Krk and Cres). A modified nonlinear method was used to calculate the livestock units (LU), based on metabolic weight defined by the ratio of livestock body mass and metabolically calibrated livestock exponentiated to ${ }^{0.75}$. An animal of $1,000 \mathrm{lbs}$ (libra) $=453.6 \mathrm{~kg}$ daily eats dry matter equivalent to $2 \%$ of its own body weight (HOLECHEK et al. 1989), with the proviso that this was recalculated according to the Croatian standard in which the body weight of a livestock 
unit is $500 \mathrm{~kg}$. The number of livestock units used for the evaluation of the pasture capability was calculated using the following formula:

Number of LU $=[$ livestock quantity $\times$ average body mass of sheep $\times($ days of livestock grazing / 365)] / 500

The average body mass of a sheep (from Pag, Cres and Krk) is $38.59 \mathrm{~kg}$ (Mioč et al. 2004, 2007, PAVIĆ et al. 2006). According to these figures, sheep grazing intensities are converted into the occupation of pasture by a livestock unit: heavy grazing intensity $(\geq 0.62$ $\mathrm{LU})$, moderate grazing intensity $(0.10 \mathrm{LU})$, and rocky pastures abandoned for more than 20 years $(0$ LU).

\section{Data analysis}

The differences between the three grazing intensities for measured soil properties were tested using the analysis of variance (ANOVA), and the data collected in the first and second matrix (flora vs. soil) were analyzed by using correlation, cluster and ordination analysis.

Degree of similarity among the studied sites of rocky pastures with respect to the floristic composition was compared with the use of cluster analysis according to the data on the presence of taxa and its abundance.

The binary similarity index according to Bray-Curtis (BRAY and CURTIS 1957) was used in the analysis of the similarities between the flora of the studied sites. In the analysis of similarity/diversity of flora, agglomerative UPGMA algorithm (Unweighted Paired Group Method using Arithmetic averages) was used.

Floristic composition of sampled plots was analyzed by applying metric multidimensional scaling - PCoA (Principle Coordinate Analysis) (Gower 1966), using the square root of the complement of Jaccard index as a measure of diversity (MR):

$$
M R=\sqrt{1-\frac{a}{a+b+c}}
$$

where, $a$ - the number of species common to both plots compared, $b$ and $c$ - the number of species occurring only in the first or in the second plot; for this purpose the program CANOCO 4.5 (TER BRAAK and ŠmilAUER 2002) was used.

The first step consisted of DCA analysis (detrended correspondence analysis), which was performed in order to determine the length of ordinal axis gradients, based on which direct gradient analysis (redundancy analysis) was selected in the second step; this assumes a linear response of species to habitat factors (within the observed range of their values).

Environmental variables were included in the redundancy analysis iteratively based on the explained variance of species and statistical significance $(\mathrm{P}<0.05)$ of the contribution of the variable to the total explained variance using the Monte Carlo permutation test.

\section{Results}

In floristic studies (LJUBIČIĆ 2012) carried out on rocky pastures of the northern Adriatic islands of Pag, Krk and Cres, 310 taxa of vascular flora were found on 60 plots $(281$ species, 27 subspecies and two varieties). The greatest number of taxa was recorded on pastures of moderate sheep grazing intensity, varying from 68 to 90 taxa per plot, on heavy intensity pastures the number of taxa varied between 49 and 74, while on abandoned pastures from 32 to 45 taxa were recorded per plot (Fig. 2). 


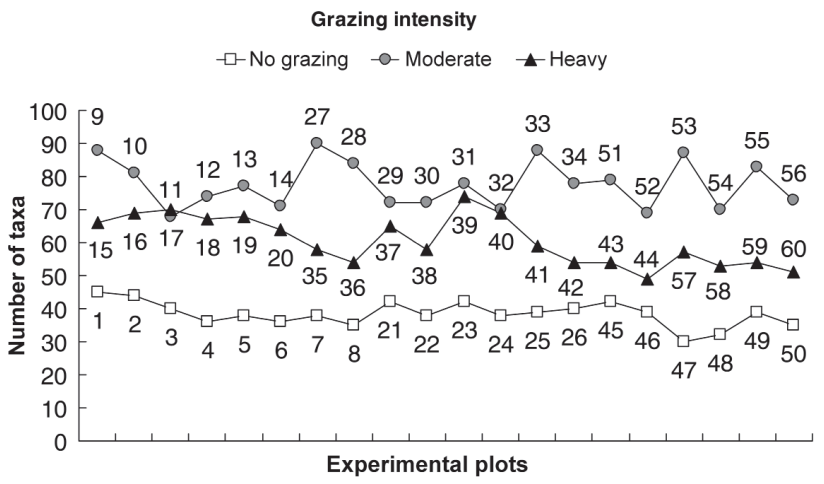

Fig. 2. The number of taxa observed on plots, according to the different grazing intensity of rocky pastures on the northern Adriatic islands; symbols from 1 to 60 mean numbers of experimental plot.

In our study the Mediterranean floral element (53.9\%) was dominant on the rocky pastures of the northern Adriatic islands. Analysis of life forms showed dominance of hemicryptophytes with $38.4 \%$ of the studied plants. Abandoned pastures are dominated by phanerophytes, at $35.5 \%$, unlike those characterized by moderate and heavy grazing intensity (Fig. 3).

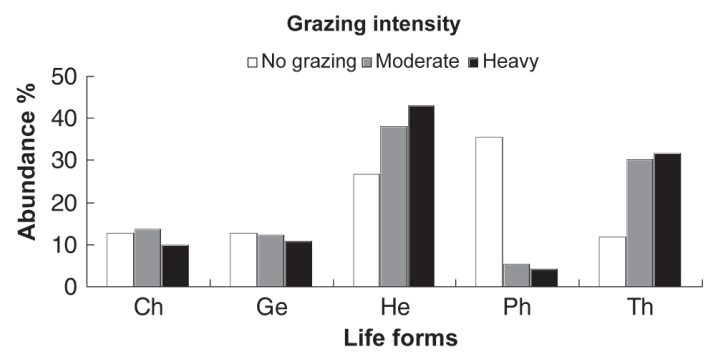

Fig. 3. Abundance of plant life forms on rocky pastures of northern Adriatic islands according to the different grazing intensities; $\mathrm{Ch}$ - chamaephytes, $\mathrm{He}$ - hemicryptophytes, $\mathrm{Ge}$ - geophytes, $\mathrm{Ph}$ - phanerophytes, $\mathrm{Th}$ - therophytes.

Signfiicantly more endemic taxa were found on plots of heavy and moderate grazing intensity, compared to plots on abandoned pastures studied. From a total of 23 established endangered taxa (LJUBIČIĆ 2012), 18 were found on plots of moderate grazing intensity, 11 on plots of heavy grazing intensity, and only six taxa were found on plots of abandoned pastures. An equal number of allochthonous species was found on plots of moderate and heavy grazing intensity, while no allochthonous species were found on plots of abandoned pastures.

The results of the measurement of soil composition on plots of rocky pastures of varying sheep grazing intensity are shown in table 1 . The highest concentration of total nitrogen and humus in the soil was found on pastures of heavy sheep grazing intensity. Statistically significant differences in the concentration of physiologically active phosphorus were determined in pastures of heavy sheep grazing intensity, pastures of moderate grazing intensity 
Tab. 1. Mean values of the basic chemical soil properties on the studied rocky pastures of the northern Adriatic islands, according to grazing intensity. Results are expressed as the arithmetic mean of 20 plots and grazing intensity. Average values within the same row marked with different letters are statistically significantly different at the level of $p \leq 0.05$.

\begin{tabular}{lccc}
\hline Soil composition & No grazing & Moderate intensity & Heavy intensity \\
\hline $\mathrm{N}(\%)$ & $0.58^{\mathrm{a}, \mathrm{c}}$ & $0.50^{\mathrm{a}}$ & $0.71^{\mathrm{b}}$ \\
$\mathrm{P}_{2} \mathrm{O}_{5}(\mathrm{mg} / 100 \mathrm{~g})$ & $1.37^{\mathrm{a}, \mathrm{c}}$ & $0.94^{\mathrm{a}}$ & $5.41^{\mathrm{b}}$ \\
$\mathrm{K}_{2} \mathrm{O}(\mathrm{mg} / 100 \mathrm{~g})$ & $84.32^{\mathrm{a}, \mathrm{b}}$ & $65.0^{\mathrm{a}}$ & $105.76^{\mathrm{b}}$ \\
$\mathrm{pH}$ & $7.19^{\mathrm{b}}$ & 7.35 & 7.48 \\
Humus (\%) & $12.45^{\mathrm{b}, \mathrm{c}}$ & $9.82^{\mathrm{a}}$ & $13.54^{\mathrm{b}, \mathrm{c}}$ \\
\hline
\end{tabular}

and abandoned pastures. The average value of physiologically active phosphorus $\left(\mathrm{P}_{2} \mathrm{O}_{5}\right)$ at the level of all plots amounts to $2.57 \mathrm{mg} / 100 \mathrm{~g}$ of soil. Mean value of the physiologically active potassium content $\left(\mathrm{K}_{2} \mathrm{O}\right)$ at the level of all plots amounts to $85.03 \mathrm{mg} / 100 \mathrm{~g}$.

Table 2 shows the correlations of the measured properties of the soil parameters, where a significantly strong positive correlation $(r=0.897)$ in the relationship of total nitrogen and humus content was found.

Tab. 2. Correlation between the properties of the soil composition on the studied rocky pastures of the northern Adriatic islands in all 60 plots and their $\mathrm{p}$ values. The cells below the diagonal contain the correlation coefficients and the cells above the diagonal the corresponding $\mathrm{p}$ values. Statistically significant correlations $(\mathrm{p} \leq 0.05)$ are in bold.

\begin{tabular}{lcrccr}
\hline & $\mathrm{N}$ & $\mathrm{P}_{2} \mathrm{O}_{5}$ & $\mathrm{~K}_{2} \mathrm{O}$ & $\mathrm{pH}$ & Humus \\
\hline $\mathrm{N}$ & & 0.0139 & 0.0697 & 0.0468 & $<0.0001$ \\
$\mathrm{P}_{2} \mathrm{O}_{5}$ & $\mathbf{0 . 3 1 6}$ & & 0.0002 & 0.0627 & 0.0018 \\
$\mathrm{~K}_{2} \mathrm{O}$ & 0.235 & $\mathbf{0 . 4 6 0}$ & & 0.6184 & 0.2428 \\
$\mathrm{pH}$ & $\mathbf{0 . 2 5 7}$ & -0.241 & 0.065 & & 0.5994 \\
Humus & $\mathbf{0 . 8 9 7}$ & $\mathbf{0 . 3 9 4}$ & 0.153 & 0.069 & \\
\hline
\end{tabular}

The results of cluster analysis based on the values of the Bray-Curtis similarity index are graphically represented by a UPGMA dendrogram (Fig. 4). The diagram clearly shows the separation and formation of three groups according to the intensity of pasture use: 1 - abandoned pastures, 2 - pastures of heavy grazing intensity and 3 - pastures of moderate sheep grazing intensity. Pastures of moderate and heavy intensity are relatively similar, while abandoned pastures form a separate cluster unlike either of them (Fig. 4).

Iterative inclusion of environmental variables on the basis of their statistical significance and proportion of explained species variance was carried out by redundancy analysis with nine environmental variables: total soil nitrogen $(\mathrm{N})$, physiologically active phosphorus $\left(\mathrm{P}_{2} \mathrm{O}_{5}\right)$, potassium $\left(\mathrm{K}_{2} \mathrm{O}\right)$, reaction soil- $\mathrm{pH}$, humus content, altitude, terrain slope, northness and eastness. Aggregate examination of redundancy analysis shows that four canonical axes explained $23.3 \%$ of species variability, and $76.7 \%$ of species variability was explained by environmental variables used in the analysis (Tab. 3). 


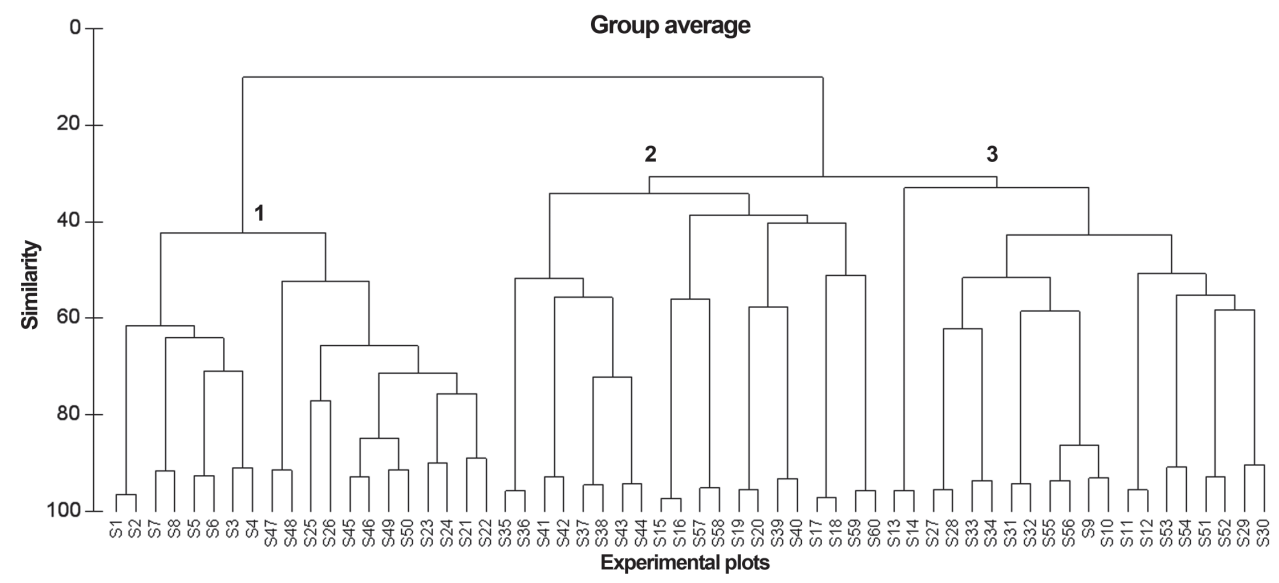

Fig. 4. Bray-Curtis similarity UPGMA dendrogram of the floristic composition of 60 rocky pasture study plots (S1-S60) on the northern Adriatic islands shows the separation of clusters into three groups, which typically belong to: 1 - abandoned pastures, 2 - pastures of heavy grazing intensity and 3 - pastures of moderate sheep grazing intensity.

Tab. 3. Results of the redundancy analysis of the first four canonical axes carried out on 60 plots, 310 species and nine environmental variables: total soil nitrogen $(\mathrm{N})$, physiologically active phosphorus $\left(\mathrm{P}_{2} \mathrm{O}_{5}\right)$, potassium $\left(\mathrm{K}_{2} \mathrm{O}\right)$, reaction soil $-\mathrm{pH}$, humus content, altitude, terrain slope, northness and eastness.

\begin{tabular}{lccccc}
\hline Axes & 1 & 2 & 3 & 4 & Total inertia \\
\hline Eigenvalues & 0.104 & 0.061 & 0.040 & 0.028 & 1.000 \\
Species-environment correlations & 0.704 & 0.701 & 0.786 & 0.797 & \\
$\begin{array}{l}\text { Cumulative percentage variance } \\
\quad\end{array}$ & 10.4 & 16.5 & 20.5 & 23.3 & \\
$\quad$ of species & & & & & \\
$\quad$ of species-environment relation & 34.4 & 54.3 & 67.5 & 76.7 & 1.000 \\
Sum of all eigenvalues & & & & & 0.304 \\
Sum of all canonical eigenvalues & & & & & \\
\hline
\end{tabular}

T-values of canonical coefficients on ordinate axis which show the significance of a certain variable on axes are listed in table 4 . The first and the second canonical axis are mostly influenced by soil parameters (humus content, nitrogen $-\mathrm{N}$ and physiologically active phosphorous $-\mathrm{P}_{2} \mathrm{O}_{5}$ ), the third by northness, while the fourth is mostly influenced by altitude and potassium $-\mathrm{K}_{2} \mathrm{O}$.

The length of the vector on the diagram of the first and second canonical axis depicting plots and environmental factors (Fig. 5a) shows that humus, $\mathrm{P}_{2} \mathrm{O}_{5}, \mathrm{~K}_{2} \mathrm{O}$ and nitrogen have the greatest influence on the changes in the floristic composition structure. The second quadrant of the biplot is dominated by plots of abandoned pastures and the drop in the value of soil reaction $(\mathrm{pH})$ is clearly noticeable. The increase in the value of $\mathrm{P}_{2} \mathrm{O}_{5}$ and humus is marked in the first quadrant, dominated by pastures of high sheep grazing intensity and the declivity of the terrain. 
Tab. 4. T-values of the canonical coefficients of environmental variables on the first four canonical axis; the highest values are marked in bold; \% variance - proportion of explained variance of certain axis.

\begin{tabular}{lrrrr}
\hline Axes & 1 & 2 & 3 & \multicolumn{1}{c}{4} \\
\hline Variance (\%) & 34.39 & 19.93 & 13.15 & 9.21 \\
$\mathrm{~N}$ & 2.99 & -1.99 & -3.24 & 1.91 \\
$\mathrm{P}_{2} \mathrm{O}_{5}$ & $\mathbf{3 . 9 6}$ & -0.40 & 0.70 & -3.47 \\
$\mathrm{~K}_{2} \mathrm{O}$ & -1.07 & 3.30 & 0.95 & 4.51 \\
$\mathrm{pH}$ & 1.94 & -1.40 & 0.75 & -0.90 \\
$\mathrm{Humus}$ & -3.60 & $\mathbf{3 . 6 3}$ & 2.74 & -1.44 \\
Organic matter & 0.00 & 0.00 & 0.00 & 0.00 \\
Height & -0.73 & -0.64 & 2.38 & $\mathbf{5 . 8 3}$ \\
Inclination & -1.20 & -0.58 & 2.80 & -2.69 \\
Northness & 1.96 & -0.57 & $\mathbf{5 . 2 2}$ & -1.23 \\
Eastness & -0.63 & 0.10 & 0.50 & -2.49 \\
\hline
\end{tabular}

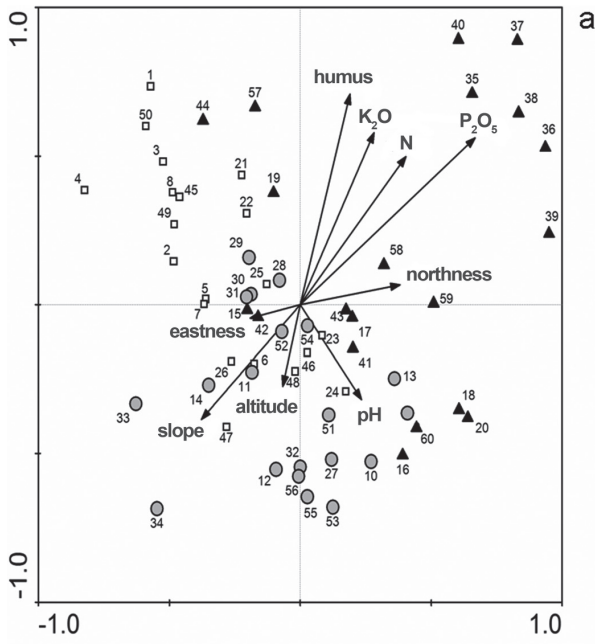

SPECIES

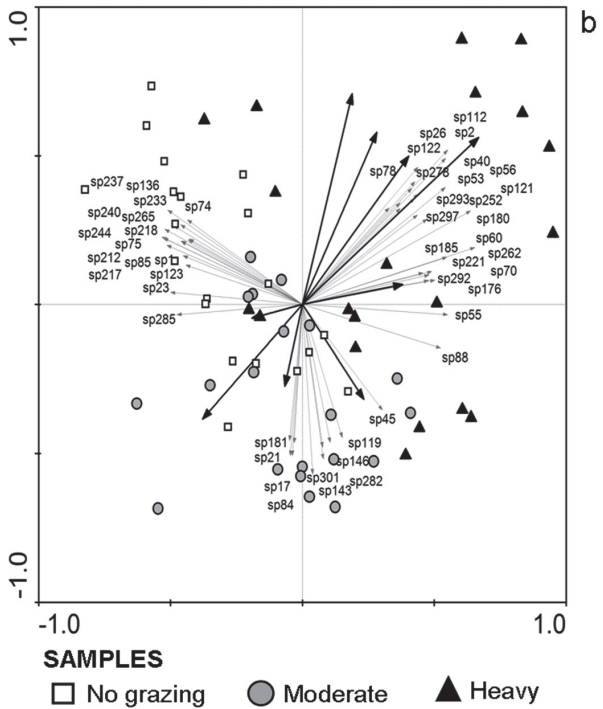

Fig. 5. Ordinate diagram of the first two canonical axes of redundancy analysis depiciting (a) experimental plots and environmental variables (indicated with dark arrows) and (b) species (the first quadrant: sp112 - Euphorbia cyparissias, sp56 - Carduus nutans, sp53 - C. micropterus, sp60 - Carlina corymbosa, etc.; the second quadrant: sp217 - Pistacia lentiscus, sp1 - Acer monspessulanum, sp233 - Quercus ilex, sp123 - Fraxinus ornus, sp85 - Coronilla emerus ssp. emeroides, sp265 - Smilax aspera, sp240 - Rubia peregrina, sp75 - Clematis flammula, sp136 - Geranium molle, sp244 - Ruscus aculeatus, etc.; the third and fourth quadrants: sp45 - Bromus erectus, sp119 - Festuca valesiaca, sp181 - Melica ciliata, sp17 - Anthoxanthum odoratum, etc.,) indicated by grey arrows and environmental variables. Simbols (circles, triangles and squares) represent experimental plots from 1 to 60 . Arrow direction marks the increase of the value, and length of arrow marks the degree of influence on the explanation of total variability on the first two axes. 
The diagram of the first and second canonical axis depicting species and environmental factors (Fig. 5b) shows vectors affected by statistically most significant species for the formation of the ordinate diagram. It is also visible that certain taxa group into clusters corresponding to specific agro-ecological factors. The first quadrant is characterized by grouping of unpalatable species: Euphorbia cyparissias L., Carduus nutans L., C. micropterus (Borbás) Teyber, Carlina corymbosa L., etc. The second quadrant of the biplot is dominated by species comprising garrigue, macchia and Mediterranean region forests: Pistacia lentiscus L., Acer monspessulanum L., Quercus ilex L., Fraxinus ornus L. and Coronilla emerus L. ssp. emeroides Boiss. et Spruner, comprised of trees and shrubs; Smilax aspera L., Rubia peregrina L. and Clematis flammula L., showing the presence of climbing plants; Geranium molle L., Ruscus aculeatus L., etc. in the ground layer. The third and fourth quadrants show a grouping of typical grassland species: Bromus erectus Huds, Festuca valesiaca Schleich. ex Gaudin, Melica ciliata L., Anthoxanthum odoratum L., etc. (Fig. 5b).

\section{Discussion}

\section{Sheep grazing intensity and plant diversity}

Sustainability of plant diversity on rocky pastures mainly depends on the sustainability of habitat, which is affected by a number of agro-ecological factors. According to a study of vegetation dynamics (VRBEK 2005), habitat sustainability is not possible without anthropogenic action. Thus, SAÏD (2001) and SAÏD and GEGout (2000), found that large areas of rocky pastures are, due to the weakening of anthropogenic influence, in the process of progressive succession threatened with being overgrown. Each succession is directly related to and influences the change in the floristic composition of plant communities (Oosting 1942, KEEVER 1950). Using the method of remote observation LJUBIČIĆ (2008) examined the overgrowing of rocky pastures on the island of Pag and found that over the past 40 years there has been significant loss of rocky pasture area, and the successive stage of macchia was significantly increased at the expense of rocky pastures. Changes in the socio-economic conditions of life on the islands of Pag, Krk and Cres have been reflected in changes in the vegetation and floristic composition. KotNIK and VIDRIH (1994) also found that the abandonment of agricultural production gradually led to the loss of the traditional patterns of rocky pastures. Successive stage of macchia has been in constant expansion in the last decade. The distribution area of macchia is mostly the rocky pasture area that is today used increasingly less for grazing. Only $30 \%$ of the overall plant diversity is related to forest habitat, $70 \%$ to open areas, and most of the latter to grassland. This shows the importance of the management of rocky pastures on the northern Adriatic islands in order to preserve the habitat and therefore the plant diversity.

The greatest number of taxa was recorded on plots of moderate grazing intensity; there was moderate diversity on plots of heavy sheep grazing intensity and on abandoned pastures the lowest number of taxa was found. These results show that the abandonment of grazing on rocky pastures encourages progressive succession and development of macchia characterized by reduced plant diversity. FuHLENDORF et al. (2001) and Floyd et al. (2003) also confirm that very intensive grazing reduces the number of species and lays bare the soil surface. By examining the response of semi-natural Mediterranean pastures to the grazing intensity Noy-MeIr et al. (1989) found changes in most of the studied taxa observed within 15 fenced plots. Thus, for example, perennial species performed better in fenced plots, and 
highly grazed pastures were dominated by thorny species. Studies of rocky pastures on the northern Adriatic islands also demonstrated that thorny taxa of the family Asteraceae are significantly more abundant on plots of higher grazing intensity (LJUBIČIĆ 2012). PUERTO et al. (1990) studied the Mediterranean grasslands of Spain and found the largest number of species on moderately grazed pastures. In addition, on these pastures they revealed the highest biomass yield. In the northern Adriatic karst grassland ŠKORNIK et al. (2010), found the greatest plant diversity on moderately grazed pastures with 4-7 sheep ha ${ }^{-1}$. For the area of rocky pastures on the northern Adriatic islands on the basis of our research there is greatest plant diversity on moderately grazed pastures with $1-1.5$ sheep ha ${ }^{-1}$. The difference in the optimal grazing intensity values between the study carried out by ŠKORNIK et al. (2010) and the present study can be explained by the greater fertility of the soil and better condition of pasture, which allows a greater number of sheep/ha as compared to our study which was conducted mainly on poor and skeletoidal soil. Basically, moderate sheep grazing intensity favors the development of plant diversity, and therefore may be considered optimal for the proper management of pastures and the preservation of plant diversity.

The presence of taxa of the family Poaceae is higher on plots of moderate sheep grazing intensity than on plots of heavy intensity while the fewest taxa of the family were found in abandoned pastures. This study showed a higher presence of taxa of the family Fabaceae on grazed plots than on ungrazed plots (LJUBIČIĆ 2012). While studying anthropogenic impacts on natural pastures, PANTISA and TZANOUDAKIS (2001), also found a higher presence of taxa of the family Fabaceae. Thus, in semi-natural systems, i.e. where grazing as an anthropogenic factor is involved, a higher presence of legume species was found in relation to allnatural habitats. On areas of abandoned pastures no taxa of the family Asteraceae were found (LJUBIČIĆ 2012). Likewise, in the study of succession processes and the invasion of allochthonous species on the islands of Galapagos, ITOw (2003) found during the process of progressive succession a gradual decrease in numbers of species of the family Asteraceae. The above phenomenon can be explained by the heliophilia of most members of the family Asteraceae and their disabled development due to the large proportion of phanerophytes in this habitat type.

\section{Floral elements and plant life forms}

The Mediterranean floral element is the most frequent in the present study of the northern Adriatic islands. In the vegetation study of the southern Adriatic islands such as the island of Svetac (Pavletić 1979) and Brusnik (Bogdanović and Mitić 2003) it was found that the Mediterranean floral element was there also the most dominant. From the above it can be concluded that the high percentage of plants belonging to Mediterranean floral elements groups confirms the Mediterranean character of rocky pastures in the study area, which is typical of other Adriatic islands as well. The endemic species (Onosma echioides (L.) L. ssp. dalmatica (Scheele) Peruzzi et N. G. Passal., Aurinia sinuata (L.) Griseb., Rhamnus intermedius Steud. et Hohst., etc.) were the least numerous on abandoned pastures where the process of progressive succession has been visible in the last 20 years. In contrast, on open habitats such as plots of optimal grazing pressure (in the present case 1.5 sheep ha ${ }^{-1}$ ) there is a favourable influence on the development and preservation of endemic species.

According to Pignatti (1982) and Ellenberg (1992), the percentage of certain plant life forms in an area indicates the local climatic and soil conditions. On abandoned pastures the proportion of phanerophytes is higher than on pastures of moderate and heavy grazing in- 
tensity. The present study also confirmed the expectedly lowest number of therophytes on abandoned pastures. The disabled development of therophytes may be explained by the progressive succession stage and the dominance of phanerophytes. In line with this are studies carried out by Š KORNIK et al. (2010), who also found that there are no therophytes on abandoned pastures. In addition, the latter authors found a significantly higher proportion of therophytes on pastures of heavy grazing intensity. The present study determined an equal presence of geophytes, regardless of the grazing intensity, which is in line with the average proportion of geophytes on the Mediterranean area and indicates the species-rich spring aspect. Such presence of life forms is a clear indication of the habitat environmental conditions and clearly separates the open pasture habitats from their progressive succession stages.

According to the list of invasive species in Croatia (Boršić et al. 2008), a low presence of allochthonous species was found in the study area, which indicates a very low rate of rocky pasture utilization and the isolation of the study area by its sea barrier. Invasive species are often pioneer species in habitats exposed to disturbances/stress (RuŠčIć 2010). Therefore, it is to be expected that increasing urbanization, increasing tourism activities and other anthropogenic factors will also cause a future increase of the number of allochthonous and invasive taxa on the rocky pastures of the northern Adriatic islands.

\section{Endangered taxa}

From our above results, it can be concluded that moderate grazing ( 1.5 sheep ha $\left.{ }^{-1}\right)$ is beneficial to the development and preservation of endangered taxa. On the other hand, overgrazing leads to changes in habitat conditions, over-fertilization by grazing animals causes further nitrification of the soil, both leading to increased abundances of nitrophilic and thorny species, which due to their unpalatability permanently remain dominant and suppress the development of endangered species. It was also found that the endangered taxa of the family Orchidaceae have the higest presence on moderately occupied pastures (LJUBIČIĆ 2012). According to the list of Croatian flora (NIKOLIĆ 2013), 7.85\% of plants are considered endangered, which is consistent with this study where the proportion of endangered plants on rocky pastures of the northern Adriatic islands is $7.42 \%$.

\section{Soil composition}

All soil parameters except the $\mathrm{pH}$ value showed the lowest values in the moderately and the highest in the intensively grazed pastures. The concentration of nitrogen in the soil is statistically significantly higher in heavily grazed compared to the moderately grazed pastures. In contrast, the study by HE et al. (2011) showed that the concentration of nitrogen (in the soil layer $0-10$ and $10-30 \mathrm{~cm}$ ) decreases linearly with an increase in the number of livestock per unit area, which can be explained by a greater amount of grazed grass and therefore less biomass for the process of humification. These authors also found that the amount of carbon in the surface soil layer $(0-10 \mathrm{~cm})$ is significantly higher in the case of moderately grazed pastures in relation to pastures of higher grazing intensity after five years of sheep grazing. These results refer to the transformation and loss of carbon from the soil under the influence of high grazing intensity, given that the threshold for this transformation is 4.5 sheep $\mathrm{ha}^{-1}$. From the above, it can be concluded that the increase in concentration of these nutrients is expected only to a certain degree of sheep grazing intensity. Based on the results obtained in present study, it was found that these soils are poor in physiologically 
active phosphorus $\mathrm{P}_{2} \mathrm{O}_{5}$. The highest concentration of $\mathrm{P}_{2} \mathrm{O}_{5}$ was measured on heavily grazed pastures, which results from the high number of sheep as nutrient vector. The results of the physiologically active potassium content $\left(\mathrm{K}_{2} \mathrm{O}\right)(>40.1 \mathrm{mg} / 100 \mathrm{~g}$ of soil) indicate the richness of the study area in this element. The high presence of physiologically active potassium may be explained as a result of fires that occurred at certain study sites as well as by the release from organic matter and sheep manure (ŠPANJOL et al. 2003, RosAVEC et al. 2013). The measured humus content corresponds to the category of high humus content soil. A strong positive correlation in the relation of humus content in the soil and total nitrogen is explained by the number of sheep as nutrient vectors. The studied plots of the rocky pastures are part of skeletal and skeletoidal soils and the very high humus content relates only to finegrained soil, therefore the obtained data are to be considered within this context.

\section{Interconnection of studied plots}

Similarity analyses based on the presence of species and values of the Bray-Curtis index show groupings of rocky pastures with respect to grazing intensity, so there is greater similarity between pastures of moderate and heavy sheep grazing intensity than between abandoned pastures and either of these two. Our results confirm what has been documented in

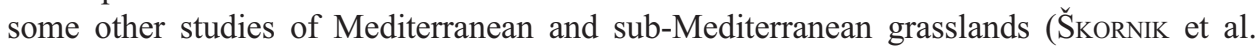
2010). This is in concordance with findings of DE BELLo et al. (2007), although they have studied a gradient of environmental factors, particularly soil moisture, which has proven to be very important as well. Our plots were situated in an environmentally more homogenous area with respect to soil moisture, and therefore the influence of grazing pressure was dominant. Similarity analyses based on abundance and values of Bray-Curtis similarity index show grouping with respect to grazing intensity, clearly separating three groups: 1 - pastures of moderate sheep grazing intensity, 2 - pastures of heavy sheep grazing intensity and 3 abandoned pastures. These results fully reflect the conditions on the rocky pasture plots, where it is clearly visible that the abandoned pasture plots are in the process of succession and overgrowth, as shown in a previous study of the island of Pag (LJUBIČić et al. 2008).

Redundancy analysis studied the interconnection of plant species with respect to environmental factors and these have accordingly been allocated into three directions from the source followed by environmental variables which could indicate different habitat types. There was a separation and grouping into three clusters according to the occupation of pastures, given that there is an overlap in certain parts between pastures of moderate and heavy sheep grazing intensity. In their canonical correspondence analysis DoBRović et al. (2006) found that the changes in altitude, $\mathrm{pH}$ and inclination had the strongest influence on changes of floristic structure, but they did not study the soil composition. In our study among other parameters, humus, $\mathrm{P}_{2} \mathrm{O}_{5}, \mathrm{~K}_{2} \mathrm{O}$ and $\mathrm{N}$ have the greatest influence on structural changes in floristic composition. The nutrient content in the soil is the most affected by an increase of the grazing pressure and a lower terrain slope, which was expected in the present study.

\section{Conclusion}

From a study of the rocky pastures of the northern Adriatic islands of Pag, Krk and Cres it is concluded that the intensity of sheep grazing has a significant impact on plant diversity and chemical composition of the soil. The greatest plant diversity was determined on pas- 
tures of moderate sheep grazing intensity. With the increase of grazing intensity the concentration of total nitrogen $(\mathrm{N})$ and humus in the soil also increases and facilitates the development of nitrophilic and unpalatable species. By contrast, the abandonment of sheep grazing leads to a progressive succession process and a growing proportion of woody plants (phanerophytes) which, due to the canopy produced, results in a significant reduction in plant diversity. Determination of the largest proportion of plants of the Mediterranean floral element confirms the Mediterranean character of the study area. Moderate grazing intensity is beneficial to the development and preservation of endemic and endangered taxa. The analysis of the similarities between the flora of the studied plots clearly distinguished three clusters with respect to the intensity of grazing. Humus, total nitrogen $(\mathrm{N})$, physiologically active phosphorus $\left(\mathrm{P}_{2} \mathrm{O}_{5}\right)$ and potassium $\left(\mathrm{K}_{2} \mathrm{O}\right)$ best explain the differences in floristic composition obtained by ordinate analyses in relation to other environmental variables. Grazing pressure and lower slope of the terrain contribute to the increase of nutrients in the soil.

For conservation and biodiversity purposes but also to for the improvement of ecological sheep farming, moderate grazing intensity ( 1 to 1.5 sheep ha ${ }^{-1}$ ) seems to be the most appropriate treatment for managing rocky pastures of the northern Adriatic islands of Pag, Krk and Cres.

\section{Acknowledgements}

We would like to thank the Department for Soil Amelioration of the Faculty of Agriculture University of Zagreb for assistance in soil sampling, and particularly Professor Marija Romić, Ph. D. for her efforts during the analyses of the soil composition.

\section{References}

Augustine, D. J., McNaughton, S. J., 1998: Ungulate effects on the functional species composition of plant comunities: Herbivore selectivity and plant tolerance. Journal of Wildlife Management 62, 1165-1183.

Biondi, E., Allegrezza, M., Zuccarello, U., 2005: Syntaxonomic revision of the Apennine grasslands belonging to Brometalia erecti, and an analysis of their relationships with the xerophilous vegetation of Rosmarinetea officinalis (Italy). Phytocoenologia 35, 129 163.

Bogdanović, S., Mitić, B., 2003: The flora of the volcanic island of Brusnik (central Dalmatia, Croatia). Acta Botanica Croatica 62, 103-113.

Boršić, I., Milović, M., Dujmović, I., Bogdanović, S., Cigić, P., ReŠEtnik, I., Nikolić, T., Miтić, B., 2008: Preliminary check-list of invanzive alien plant species (IAS) in Croatia. Natura Croatica 17, 55-71.

Bray, J. R., Curtis, J. T., 1957: An ordination of upland forest communities of southern Wisconsin. Ecological Monographs 27, 325-349.

Cingolani, A. M., Noy-Meir, I., Díaz, S., 2005: Grazing effects on rangeland diversity: a synthesis of contemporary models. Ecological Applications 15, 757-773.

Cousins, S., Eriksson, A., 2001: Plant species occurrences in a rural hemiboreal landscape: Effects of remnant habitats, site history, topography and soil. Ecography 24, 461-469. 
de Bello, F., Lepš, J., Sebastia, M. T., 2007: Grazing effects on the species-area relationship: Variation along a climatic gradient in NE Spain. Journal of Vegetation Science 18, $25-34$.

Derner, J. D., Schuman, G. E., 2007: Carbon sequestration and rangeland: A synthesis of land management and precipitation effects. Journal of Soil and Water Conservation 62, 77-85.

Dobrović, I., Safner, T., Jelaska, S. D., Nikolić, T., 2006: Ecological and phytosociological characteristics of the association Abieti-Fagetum »pannonicum « Rauš 1969 prov. on Mt. Medvednica (NW Croatia). Acta Botanica Croatica 65, 41-55.

Eler, K., VIDRIH, M., BATIČ, F., 2005: Vegetation characteristics in relation to different management regimes of calcareous grassland: A functional analysis using plant traits. Phyton $45,417-426$.

Ellenberg, H., Weber, H. E., Dull, R., Wirth, V., Werner, W., Paulissen, D., 1992: Zeigerwerte von Pflanzen in Mitteleuropa. Scripta Geobotanica 18, 1-285.

Floyd, M. L., Fleischner, T. L., Hanna, D., Whitefield, P., 2003: Effects of historic livestock grazing on vegetation at Chaco Culture National Historical Park, New Mexico. Conservation Biology 17, 1703-1711.

Frank, D. A., Groffman, P. M., 1998: Ungulate vs. landscape control of soil C and N processes in grasslands of Yellowstone National Park. Ecology 79, 2229-2241.

Fuhlendorf, S. D., Briske, D. D., Smeins, F. E., 2001: Herbaceous vegetation change in variable rangeland environments: The relative contribution of grazing and climatic variability. Applied Vegetation Science 4, 177-188.

Gower, J. C., 1966: Some distance properties of latent root and vector methods used in multivariate analysis. Biometrika 53, 325-338.

Han, G. D., Hao, X. Y., Zhao, M. L., Wang, M. J., Ellert, B. H., Willms, W., Wang, M. J., 2008: Effect of grazing intensity on carbon and nitrogen in soil and vegetation in a meadow steppe in Inner Mongolia. Agriculture Ecosystems and Environment 125, $21-$ 32.

He, N. P., Zhang, Y. H., Yu, Q., Chen, Q. S., Pan, Q. M., Zhang, G. M., Han, X. G., 2011: Grazing intensity impacts soil carbon and nitrogen storage of continental steppe. Ecosphere 2, 1-10.

Holechek, J. L., Pieper, R. D., Herbel, C. H., 1989: Range management: principles and practices. Upper Saddle River, USA: Prentice Hall.

Horvat, I., 1949: Plant communities (in Croatian). Nakladni zavod Hrvatske, Zagreb.

Horvat, I., 1963: Forest's plant communities of Yugoslavia (in Croatian). Šumarska enciklopedija II, Zagreb.

Husnjak, S., Šimunić, I., Turšić, I., 2008: Soil erosion risk in Croatia. Cereal Research Communications 36, 939-942.

Ingram, L. J., Schuman, G. E., Buyer, J. S., Vance, G. F., Ganjegunte, G. K., Welker, J. M., Derner, J. D., 2008: Grazing impacts on soil carbon and microbial communities in a mixed-grass ecosystem. Soil Science Society of America Journal 72, 939-948.

Iтош, S., 2003: Zonation pattern, succession process and invasion by aliens in species-poor insular vegetation of the Galápagos Islands. Global Environmental Research 7, 39-58. 
Keever, C., 1950: Causes of succession on old fields of the Piedmont, North Carolina. Ecological Monographs 20, 229-250.

Knapp, A. K., Blair, J. M., Briggs, J. M., Collins, S. L., Hartnett, D. C., Johnson, L. C., Towne, E. G., 1999: The keystone role of bison in North American tallgrass prairie. BioScience 49, 39-50.

KotNIK, T., VIDRIH, T., 1994: Changes in floristic composition of the karst pasture during the growing season. Znanost i praksa u poljoprivredi i prehrambenoj tehnologiji 24, 156161.

LJUBIČIĆ, I., 2008: Vegetation dynamics and plant diversity on the rocky pastures on the island of Pag (in Croatian). MSc. Thesis, University of Zagreb, Faculty of Science, Zagreb.

Luubičić, I., Britvec, M., Kutnjak, H., Salopek, Z., Jelaska, S. D., 2008: Mapping vegetation succession of pastures on rocky soils using GIS: a case-study on the island of Pag. Cereal Research Communications 36(5), part 1, 359-362.

LJUBIČÍ, I., 2012: Influence of sheep grazing on the plant diversity of rocky pastures on the northadriatic islands (in Croatian). PhD. Thesis, University of Zagreb, Faculty of Agriculture, Zagreb.

Milchunas, D. G., Sala, O. E., Lauenroth, W. K., 1988: A generalized model of the effects of grazing by large herbivores on grassland community structure. The American Naturalist 132, 87-106.

Mioč, B., Pavić, V., Ivanković, A., Barać, Z., Vnučec, I., ČoKljat, Z., 2004: Exterior charachteristics and blood protein polymorphisms of Krk sheep (in Croatian). Stočarstvo 58, 331-341.

Mioč, B., Pavić, V., Prpić, Z., Vnučec, I., Barać, Z., Sušić, V., 2007: Exterior characteristics of Istrian sheep (in Croatian). Proceedings of $42^{\text {nd }}$ Croatian and $2^{\text {nd }}$ International symposium on Agriculture, Opatija, 552-555.

Montalvo, J., Casado, M. A., Levassor, C., Pineda, F. D., 1993: Species diversity patterns in Mediterranean grasslands. Journal of Vegetation Science 4, 213-222.

Nikolić, T., (ed.) 2013: Flora Croatica Database. University of Zagreb, Faculty of Science. Retrieved from http://hirc.botanic.hr/fcd.

Noy-Meir, I., Gutman, M., Kaplan, Y., 1989: Responses of Mediterranean grassland plants to grazing and protection. Journal of Ecology 77, 290-310.

Noy-Meir, I., Oron, T., 2001: Effects of grazing on geophytes in Mediterranean vegetation. Journal of Vegetation Science 12, 749-760.

Oosting, H. J., 1942: An ecological analysis of the plant communities of Piedmont. North Carolina. The American Midland Naturalist Journal 28, 1-126.

Pantisa, M., Tzanoudakis, D., 2001: A Floristic Investigation of the Islet Groups Arki and Lipsi (East Aegean Area, Greece). Folia Geobotanica 36, 265-279.

Pavić, V., Mioč, B., Sušić, V., Barać, Z., VnučEc, I., Prpić, Z., Čokluat, Z., 2006: Exterior characteristics of Cres sheep (in Croatian). Stočarstvo 60, 3-11.

PAvletić, Z., 1979: Analysis of the flora of the island of Svetac (in Croatian). Acta Botanica Croatica 38, 155-162. 
Peco, B., Espigares, T., Levassor, C., 1998: Trends and fluctuations in species abundance and richness in Mediterranean annual pasture. Applied Vegetation Science 1, 21-28.

Pignatti, S., 1982: Flora d'Italia I-III. Edagricole, Bologna.

Proulx, M., Mazumder, A., 1998: Reversal of grazing impact on plant species richness in nutrient-poor vs. nutrient-rich ecosystems. Ecology 79, 2581-2592.

Puerto, A., Rico, M., Matias, M. D., Garcia, J. A., 1990: Variation in structure and diversity in Mediterranean grasslands related to trophic status and grazing intensity. Journal of Vegetation Science 1, 445-452.

Rietkirk, M., VAn De Koppel J., 1997: Alternate stable states and threshold effects in semiarid grazing systems. Oikos 79, 69-76.

Rook, A. J., Dumont, B., Isselstein, J., Osoro, K., Wallisdevries, M. F., Parente, G., Mills, J., 2004: Matching type of livestock to desired biodiversity outcomes in pastures - a review. Biological Conservation 119, 137-150.

RosaVec, R., ŠIKIĆ, Z., Španjol, Ž., BARČIĆ, D., VuČETIĆ, M., 2013: Wildfire threats within the habitat conditions in Aleppo pine stands (Pinus halepensis Mill.) of Adriatic karst area (in Croatian). Šumarski list 9(10), 461-471.

Ruščić, M., 2010: Flora of the island of Brač (in Croatian). PhD. Thesis, University of Zagreb, Faculty of Science, Zagreb.

SAÏD, S., 2001: Floristic and life form diversity in post-pasture successions on a Mediterranean island (Corsica). Plant Ecology 162, 67-76.

SAïd, S., Gegout, J. C., 2000: Using the age of the oldest woody specimen for post-pasture successions in Corsica (Mediterranean island). Acta Oecologica 21, 193-201.

Salminen, R., Tarvainen, T., Demetriades, A., Duris, M., Fordyce, F. M., 1998: FOREGS geochemical mapping field manual. Geological survey of Finland 47.

Su, Y. Z., Li, Y. L., Cui, J. Y., ZHAO, W. Z., 2005: Influences of continuous grazing and livestock exclusion on soil properties in a degraded sandy grassland. Catena 59, 267-278.

ŠKornik, S., ViDrih, M., Kaligarič, M., 2010: The effect of grazing pressure on species richness, composition and productivity in North Adriatic Karst pastures. Plant Biosystems 144, 355-364.

Šsanjol, Ž., Š Egotić, K., JazBeC, A., Hitrec, V., 2003: Some factors concerning the issue of forest fires in the Mediterranean part of the Republic of Croatia. Ekologia (Bratislava) $22,60-68$.

ter BraAk, C. J. F., Šmilauer, P., 2002: CANOCO Reference manual and CanoDraw for Windows User's guide: Software for Canonical Community Ordination (version 4.5). Microcomputer Power (Ithaca, NY, USA).

TrinAJSTIĆ, I., 2008: Plant communities of Croatia (in Croatian). Akademija šumarskih znanosti, Zagreb.

VRBEK., M., 2005: Flora and non-forest vegetation of Žumberak (in Croatian). PhD. Thesis, University of Zagreb, Faculty of Science, Zagreb. 